\title{
Train-Based Platform for Observations of the Atmosphere Composition (TROICA Project)
}

\author{
N.F. Elansky¹, I.B. Belikov¹, O.V. Lavrova' ${ }^{1}$, A.I. Skorokhod1, \\ R.A. Shumsky ${ }^{1}$, C.A.M. Brenninkmeijer ${ }^{2}$ and O.A. Tarasova ${ }^{3}$ \\ ${ }^{1}$ A.M. Obukhov Institute of Atmospheric Physics RAS \\ ${ }^{2}$ Max Planck Institute for Chemistry \\ ${ }^{3}$ World Meteorological Organization \\ ${ }^{1}$ Russia \\ ${ }^{2}$ Germany \\ ${ }^{3}$ Switzerland
}

\section{Introduction}

Composition of the Earth's atmosphere is evolving in time in continuous interaction with the land, ocean, and biosphere. Growth of the world's population leads to increased human impact on the nature, causing substantial changes in atmospheric composition due to additional emissions of gases and particles. The concerns about the consequences of the human induced changes have resulted in the ratification of several important international agreements regulating anthropogenic emissions of different substances. To understand the reasons and consequences of the atmospheric composition change complex multicomponent global observations are essential. In spite of the long enough history of the observations several parts of the world still remain sparsely covered by observations, and Russia is among such regions.

Due to a huge territory and diverse climatic conditions it is extremely difficult to cover the territory of the world's biggest country, Russia, by the observational network of the proper spatial resolution. Moreover, disproportions of the industrial development of different regions, the dominance of natural resource-based industry, and varied application of imperfect technologies, have produced non-uniformities in pollution level in the different regions of the country. At the same time, over $65 \%$ of the territory contains almost no industrial activity, and the ecosystem state is close to the background conditions.

Ecosystems are very diverse in Russia as well. The Russian boreal forests (73\% of the world area of such forests), wetlands and peatland ecosystems are the most capacious reservoir of carbon and powerful sources/sinks of the greenhouse and reactive gases. These systems are climate sensitive and need careful assessment under changing conditions.

Due to degradation of the efficiency of the Russian meteorological network in the beginning of 1990s and termination of the background monitoring of $\mathrm{O}_{3}, \mathrm{NOx}, \mathrm{SO}_{2}$, and aerosol by many stations the question arose on how to continue with the observations of the key 
pollutants in the most efficient way. In this crucial period (February, 1995) Dr. Prof. P.J. Crutzen proposed to the director of the A.M. Obukhov Institute of Atmospheric Physics (OIAP), academician G.S. Golitsyn, carrying out observations of surface ozone and its precursors from a passenger train moving along the Trans-Siberian Railroad. In NovemberDecember 1995 the first experiment of such kind was performed utilizing a specialized carlaboratory. Experience of the first campaign demonstrated that reliable information on the regional boundary layer composition can be obtained if the car-laboratory is coupled at the head of a train moving along electrified railroads (Crutzen et al., 1996). Since then the experiments are performed on a regular basis and comprise the Trans-Continental (or TransSiberian) Observations Into the Chemistry of the Atmosphere (TROICA) project.

The routes and the dates of expeditions are summarized in Table 1. TROICA expeditions were mainly performed along the Trans-Siberian Railroad on the Moscow-Khabarovsk or Moscow-Vladivostok routes. The most complicated program was performed in 2000; it consisted of monitoring along the railroad from Murmansk to Kislovodsk and monitoring based on stationary scientific stations located on the Kola Peninsula, in central regions of Russia, in the town of Kislovodsk, and in the mountainous North-Caucasian region. The measurements were performed everywhere in "local spring" allowing for study of the transition from winter to summer conditions.

\begin{tabular}{|l|l|l|}
\hline Experiment & Date & Route \\
\hline TROICA-1 & $17 / 11-2 / 12 / 1995$ & N.Novgorod-Khabarovsk-Moscow \\
\hline TROICA-2 & $26 / 07-13 / 08 / 1996$ & N.Novgorod-Vladivostok-Moscow \\
\hline TROICA-3 & $1 / 04-14 / 04 / 1997$ & N.Novgorod-Khabarovsk-Moscow \\
\hline TROICA-4 & $17 / 02-7 / 03 / 1998$ & N.Novgorod-Khabarovsk-N.Novgorod \\
\hline TROICA-5 & $26 / 06-13 / 07 / 1999$ & $\begin{array}{l}\text { N.Novgorod-Khabarovsk-Moscow } \\
\text { Ob river beating }\end{array}$ \\
\hline TROICA-6 & $6 / 04-25 / 06 / 2000$ & $\begin{array}{l}\text { Moscow-Murmansk-Kislovodsk-Kislovodsk- } \\
\text { Observations at 4 stations }\end{array}$ \\
\hline TROICA-7 & $27 / 06-10 / 07 / 2001$ & Moscow-Khabarovsk-Moscow \\
\hline TROICA-8 & $19 / 03-1 / 04 / 2004$ & Moscow-Khabarovsk-Moscow \\
\hline TROICA-9 & $4 / 10-18 / 10 / 2005$ & Moscow-Vladivostok-Moscow \\
\hline TROICA-10 & $4 / 10-7 / 10 / 2006$ & Around and cross-section of Moscow megacity \\
\hline TROICA-11 & $22 / 07-5 / 08 / 2007$ & Moscow-Vladivostok-Moscow \\
\hline TROICA-12 & $21 / 07-4 / 08 / 2008$ & Moscow-Vladivostok-Moscow \\
\hline TROICA-13 & $9 / 10-23 / 10 / 2009$ & Moscow-Vladivostok-Moscow \\
\hline TROICA-14 & $26 / 05-24 / 06 / 2010$ & Moscow-Murmansk-Sochi-Murmansk-Moscow \\
\hline TROICA-15 & $7 / 12-10 / 12 / 2010$ & Moscow-S.-Petersburg- N.Novgorod-Moscow \\
\hline
\end{tabular}

Table 1. TROICA experiments: dates and routes.

In October 2006, the Moscow megacity was circumnavigated (mean radius $\sim 70 \mathrm{~km}$ ) three times via the electrified circuit railroad and Moscow city was traversed twice (TROICA-10). In the course of the TROICA-5 experiment, shipboard atmospheric monitoring was performed while traveling down the $2000 \mathrm{~km}$ Ob River starting from the city of Novosibirsk. 


\section{TROICA observing system}

In 2003 OIAP together with the Russian Research Institute of Railway Transport (RRIRT) constructed and equipped a new mobile laboratory (Fig.1). It consists of two cars intended for continuous measurements of gas and aerosol concentrations and of radiative and meteorological parameters. It also housed equipment for chemical analysis of air, water, soil, and vegetation samples (Elansky, 2007; Elansky et al., 2009). Interior of the car is shown in Fig.2.
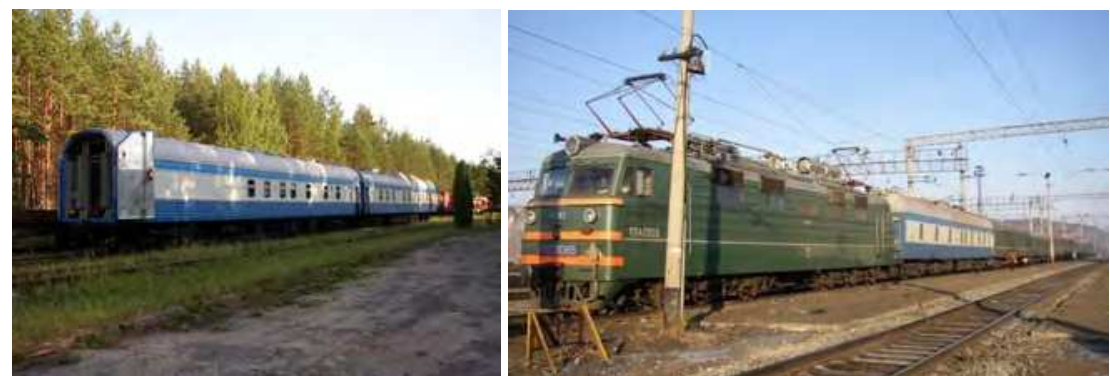

Fig. 1. Mobile laboratory for TROICA experiments (from TROICA-8 on) and its set up in the passenger train.
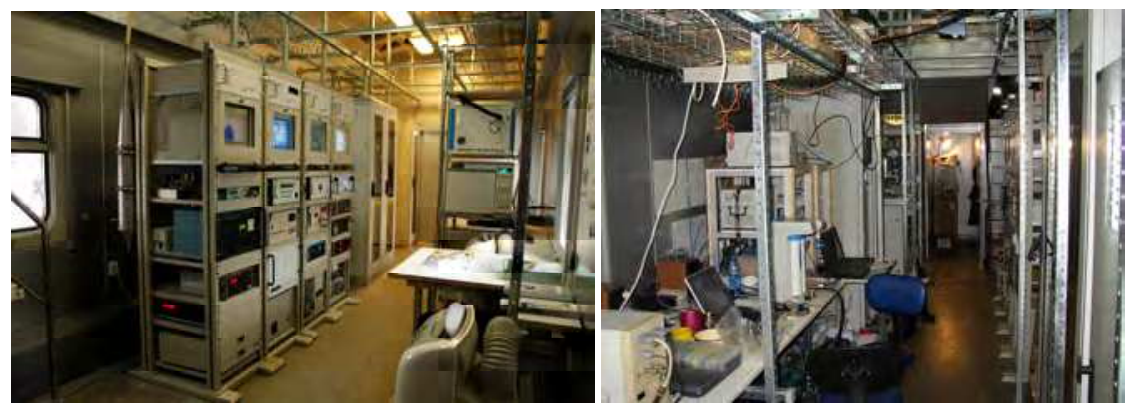

Fig. 2. Interior of the laboratory for atmospheric monitoring.

Since January 2009, the scientific instrumentation included the:

- instruments for continuous measurement of the gas mixing ratios: gas analyzers, chromatographs, PTR-MS;

- instruments for continuous measurements of concentration and microphysical characteristics of aerosols: particle counters, nephelometers, aerosol spectrometer, aetholometer, trap for bio-aerosol and radiometer-spectrometer analyzing gammaradiation;

- instruments for remote sounding of the composition of the troposphere and the middle atmosphere: photometer, spectrophotometers operating in the UV-VIS and IR spectral regions (including MAX-DOAS and microwave spectro-radiometer);

- instruments for measurements of the solar radiation, optical and meteorological characteristics of the atmosphere: spectrometer, fluxmeters operating in the UV, VIS and IR spectral regions, photometers for determining the rate of $\mathrm{NO}_{2}$ photodissociation, a temperature profiler, sonic anemometer and meteorological sensors; 
- $\quad$ systems for collection of gas and aerosol samples and instruments for express chemical analysis of some samples (gas chromatographs, mass-spectrometer, x-ray fluorimeter);

- integrated (combined with GIS) PC-system for data collection;

- communication TV and audio systems

For some special experiments various instruments belonging to the partner institutions were deployed, namely, multi-channel chromatograph ACATS-IV (NOAA-ESRL, Hurst et al., 2004); proton-transfer-reaction mass spectrometer (MPIC); different mobility particle sizer, air ion spectrometer, humidity - tandem differential mobility analyzer (UH); particle into liquid sampler with ion chromatograph, aethalometer (FMI); and some others.

A computerized integrated instrumentation set was developed for continuous atmospheric observations on the basis of the mobile laboratory. Detailed description of the used instruments can be found in the TROICA related publications.

It is important to estimate the degree of influence of the leading train and of oncoming trains in the area where the measurements are performed for adequate interpretation of the results obtained from the TROICA mobile observatory. Detailed analysis of the collected dataset showed that measurements performed on board of the laboratory moving along electrified railroads (air samples are taken above the roof just after locomotive) is capable of reflecting the principal peculiarities of the background state of the atmosphere over the continent. However, under calm conditions with nighttime temperature inversions, air pollution along the route can be accumulated within the boundary layer and in these cases a railroad can be considered as an enterprise polluting the atmosphere (Panin et al., 2001).

Therefore prior to the analysis of the phenomena of different scale all data were separated into several groups representing different pollution conditions, namely polluted (urban and industrial) and unpolluted (rural) route sections. The special and temporal features of trace gases variations were analyzed for each group separately.

\section{Gases and aerosol over the continent}

\subsection{Surface ozone variations}

Most of the observations were performed along the Trans-Siberian railroad covering a belt of the North-Eurasia between $48^{\circ}$ and $58^{\circ} \mathrm{N}$ and $37^{\circ}$ and $135^{\circ} \mathrm{E}$ (exclusive of the KhabarovskVladivostok zonal route section). The entire data file was divided into two groups of data corresponding to polluted areas (towns/villages and industrial regions) and unpolluted areas. The regions with the $\mathrm{NO}$ and $\mathrm{CO}$ mixing rations lower than $0.4 \mathrm{ppb}$ and $0.2 \mathrm{ppm}$, respectively, were taken as the unpolluted areas; the rest regions were considered as the polluted ones.

Surface ozone mixing ratio was measured with 1008RS and 1008AH gas analyzers Dasibi. These instruments are based on the photometric method. They are capable of measuring mixing ratios in the range from 1 to $1000 \mathrm{ppb}$ with a total uncertainty of $\pm 1 \mathrm{ppb}$.

Analysis of the data of all expeditions shows that minimum ozone mixing ratios were observed in the boundary layer under nighttime temperature inversions. Maximum mixing ratios were always associated with daytime conditions which are favorable for ozone generation. The spatial distribution of ozone is characterized by slight zonal gradient to the 
East with a magnitude of $0.47 \pm 0.02 \mathrm{ppb}$ per 10 degrees longitude. Such a spatial gradient is probably due to increasing availability of precursors toward the eastern part of the country (biogenic $\mathrm{CH}_{4}$ and VOC emissions in Siberia, forest fires, transport of ozone precursors from China), intensive air exchange between stratosphere and troposphere over east continental regions, and some other factors (Crutzen et al., 1998; Elansky et al., 2001b; Golitsyn et al., 2002; Markova \& Elansky, 2002).

Analysis of the campaign averaged ozone mixing ratios under unpolluted conditions showed that spring campaigns are characterized by the highest ozone mixing rations. This is likely to be connected with intensive stratosphere-troposphere exchange (Shakina et al., 2001), bringing ozone from the stratosphere, especially at the eastern part of the continent. The absence of the pronounced summer maximum, which is often reported for the stations in the Central Europe, indicates that photochemical ozone production in temperate latitudinal belt of the substantial part if Eurasia is weak and that ozone destruction under powerful continental temperature inversions plays very important role.

Diurnal variations of the surface ozone mixing ratio averaged over several expeditions and over the whole expedition route (Fig.3) confirm an important role of vertical mixing and ozone destruction on the surface by pronounced morning minimum and daily maximum (re-build ozone levels due to the developed mixing in the boundary layer). Comparison of the diurnal variations for different seasons allowed estimation of the average rate of ozone dry deposition over extended continental regions: 0.08 and $0.65 \mathrm{~cm} / \mathrm{s}$ on the surfaces covered and not covered with snow, respectively (Elansky et al., 2001b).

\subsection{Nitrogen oxides variations}

Nitrogen oxides distribution along the route is characterized by high and quite localized peaks, associated with main anthropogenic emission sources (Markova et al, 2004). The city plumes stretch over several tens of kilometers and, under some conditions, can reach even several hundreds of kilometers (e.g. under stable atmospheric stratification with slow mixing in the boundary layer).

The $\mathrm{NO}$ and $\mathrm{NO}_{2}$ mixing ratios were measured in different expeditions either with TE42CTL instrument (Thermo Electron Corp., USA) or with M200AU instrument produced by Teledyne Corp. (USA). Both instruments are based on the chemiluminescent method. The minimum $\mathrm{NO}$ and $\mathrm{NO}_{2}$ mixing ratios detectable with these instruments are $0.05 \mathrm{ppb}$ allowing for measurements under unpolluted conditions.

Numerous anthropogenic emission sources in the latitudinal belt $48-58^{\circ} \mathrm{N}$ lead to the excesses in the $\mathrm{NO}$ and $\mathrm{NO}_{2}$ mixing ratios averaged over this part of the route (all data) above $\mathrm{NO}$ and $\mathrm{NO}_{2}$ mixing ratios measured at background (unpolluted) conditions. The excess in $\mathrm{NO}_{2}$ mixing ratio is less pronounced than the one in NO mixing ratio (Markova et al, 2004) due to the fact that $\mathrm{NO}$ is a primary form for nitrogen oxides emission while $\mathrm{NO}_{2}$ is already oxidized and diluted. There was no strong seasonal cycle detected in the NOx mixing rations. Diurnal cycle of NOx is also weak in the considered latitudinal belt, except for the NO mixing ratio which is enhanced during the daytime over small and large cities as a result of household heating. Burning of the dry grass in spring and autumn can have some impact on NOx levels as well. 


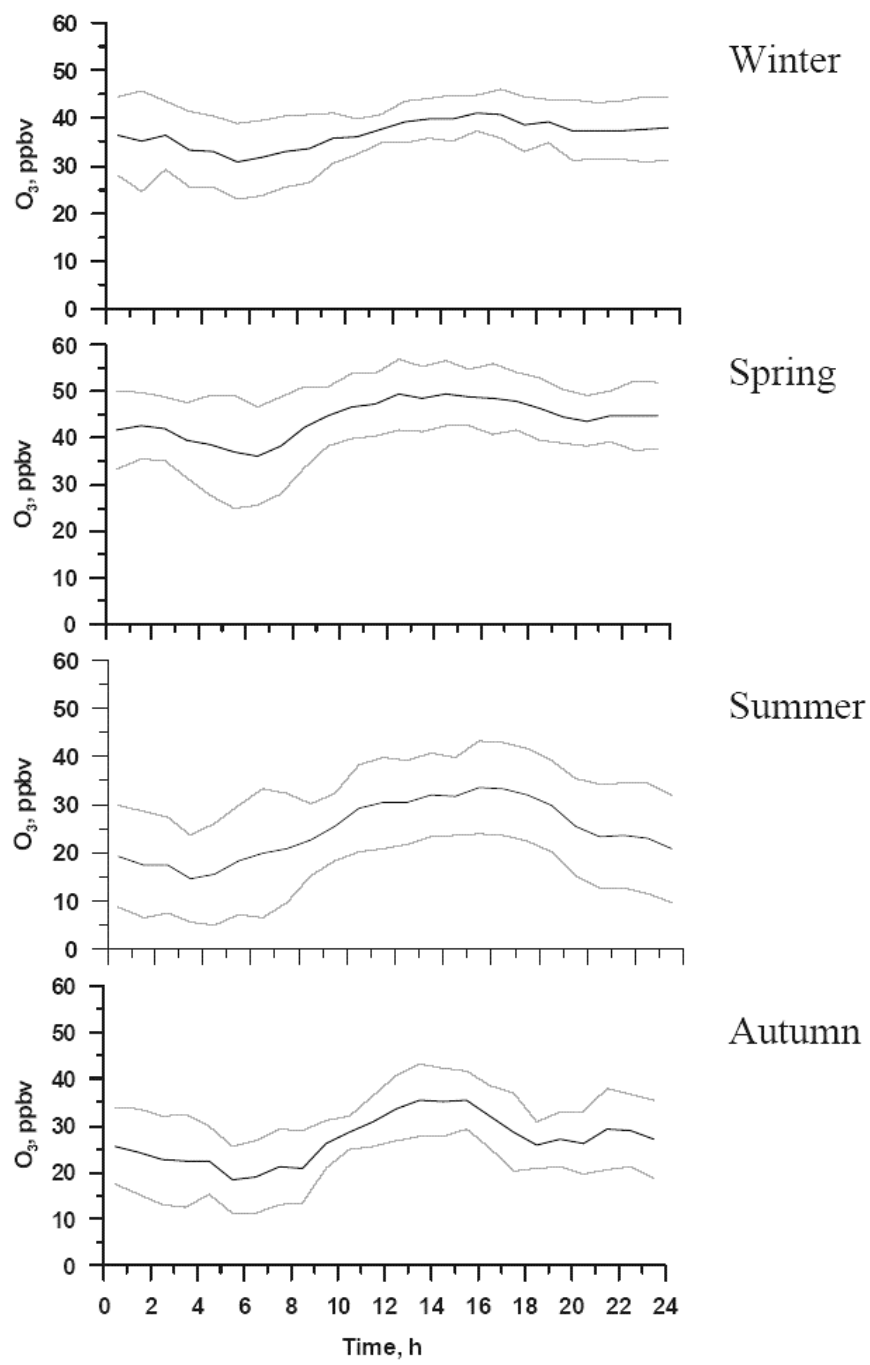

Fig. 3. Mean daily variations of ozone mixing ratio along Moscow - Vladivostok route.

\subsection{Carbon compounds $\mathrm{CO}, \mathrm{CO}_{2}$ and $\mathrm{CH}_{4}$}

Observations of carbon dioxide and methane were used to study natural and anthropogenic sources of these important long-lived greenhouse gases. Taking into consideration diversity of ecosystems across the Eurasian continent and very limited availability of the stationary observations, train based observations can be used to validate emission inventories used for atmospheric greenhouse gas modeling.

Carbon monoxide (CO) mixing ratios were detected continuously using an automated infrared absorption gas filter correlation instrument TE48S instrument (Thermo Electron 
Corp). It allows for measuring background CO mixing ratios at a level of less than $100 \mathrm{ppb}$ with the total uncertainty of $\pm 10 \mathrm{ppb}$.

Carbon dioxide $\left(\mathrm{CO}_{2}\right)$ measurements were carried out in situ using a differential nondispersive infrared analyzer LI-6262 (LiCor, USA). The measurement range is 0-3000 ppm. The outputs from the analyzer were averaged over 10-min periods and reported in ppm on a dry air basis. The accuracy of the measurements is $\pm 1 \mathrm{ppm}$.

Mixing ratios of $\mathrm{CH}_{4}$ and non-methane hydrocarbons (NMHC) were measured with APHA360 instrument (Horiba Company, Japan). This gas analyzer separates $\mathrm{CH}_{4}$ and $\mathrm{NMHC}$ using selective catalytic absorbers and measures gas mixing ratios with a flame-ionization detector. The total uncertainty of $\mathrm{CH}_{4}$ and NMHC mixing ratio measurements doesn't exceed $\pm 5 \mathrm{ppb}$. To supply the flame-ionization detector with hydrogen necessary for its operation, the instrumentation set included hydrogen generators of different types.

Observation of $\mathrm{CO}, \mathrm{CH}_{4}$ and $\mathrm{CO}_{2}$ averaged over 10 degrees latitude for different seasons are presented in Fig. 4. The plot shows no systematic large scale gradient either Eastward or Westward in $\mathrm{CO}_{2}$ spatial distribution. Analysis of $\mathrm{CO}_{2}$ diurnal variations (Belikov et al., 2006) demonstrated that high $\mathrm{CO}_{2}$ mixing ratios are observed during night-time, when vegetation and soil respiration fluxes are intensive and mixing is weak, so that $\mathrm{CO}_{2}$ is accumulated in the boundary layer under temperature inversions. In industrial regions $\mathrm{CO}_{2}$ from anthropogenic sources is accumulated as well. $\mathrm{CO}_{2}$ peaks in many cases are accompanied by the accumulation of anthropogenic $\mathrm{CH}_{4}$.

Important findings on the key greenhouse gases and $\mathrm{CO}$ distribution and variability are summarized in the number of papers (Oberlander et al., 2002; Belikov et al., 2006, Tarasova et al., 2005a and Tarasova et al., 2005b). Below the results are presented for rural areas, where anthropogenic emissions do not influence observed mixing ratios.

Mean CO mixing ratio equals to $0.21 \pm 0.03 \mathrm{ppm}$ for the cold periods. For warm periods, the mean CO mixing ratio is significantly lower, $0.12 \pm 0.03 \mathrm{ppm}$. This seasonality is controlled by $\mathrm{CO}$ sink in the reaction with $\mathrm{OH}$ in summer, which is rather typical for unpolluted stations in the mid latitudes (Tarasova et al., 2005b). CO distribution function is a bit broader for winter, showing bigger variability around the average than in summer months. Such variability is connected with a higher stability of the PBL in winter than in summer, which leads to irregular accumulation of $\mathrm{CO}$ from local sources along the train track.

Different shape of the distribution function is observed for $\mathrm{CO}_{2}$ in different seasons (Belikov et al., 2006). If in winter $\mathrm{CO}_{2}$ distribution is quite narrow and most of values are in the range $380-400 \mathrm{ppm}$, then in summer period, active biosphere causes substantial variations in $\mathrm{CO}_{2}$ mixing ratio, especially under the influence of strong surface temperature inversions. The mean summertime $\mathrm{CO}_{2}$ mixing ratio is $376 \pm 34 \mathrm{ppm}$. Excess of the winter $\mathrm{CO}_{2}$ levels over the summer ones demonstrates that biosphere in the studied latitudinal belt of Russia servers as a sink for $\mathrm{CO}_{2}$. Nevertheless, summer peaks in $\mathrm{CO}_{2}$ (e.g. under night temperature inversions or in the zones of biomass burning) exceed winter $\mathrm{CO}_{2}$ levels which are primarily controlled by anthropogenic sources.

The frequency distribution of $\mathrm{CH}_{4}$ mixing ratios is similar to that of $\mathrm{CO}_{2}$ (Tarasova et al., 2005a; Belikov et al., 2006); however, the $\mathrm{CH}_{4}$ mixing ratio depends on the surface temperature inversions to a lesser degree than $\mathrm{CO}_{2}$ mixing ratio does. 
Figure 4 shows spatial gradients of $\mathrm{CO}, \mathrm{CO}_{2}$ and $\mathrm{CH}_{4}$ over the continent during cold and warm seasons (averaged over two expeditions each time). As it can be seen in the figure, $\mathrm{CO}$ distribution over the continent in cold periods is almost uniform. Rather small elevations of the longitudal zone averages are observed for the parts of the route which include big cities and their plumes. Longitudinal gradient of $\mathrm{CO}$ mixing ratio of $0.6 \mathrm{ppb} /$ degree in the East direction, is clearly pronounced in Siberia in warm periods. This gradient is connected with intensive biomass burning in Eastern Siberia and Far East, which is known to be a substantial $\mathrm{CO}$ emission source.

$\mathrm{CO}_{2}$ spatial distribution (Fig. 4) in cold periods is also almost uniform. The non-uniformities observed in warm periods are caused by variations in the landscape and vegetation. These variations are unlikely to be connected with anthropogenic sources as they are either seasonally independent or would be stronger in winter (heating season).

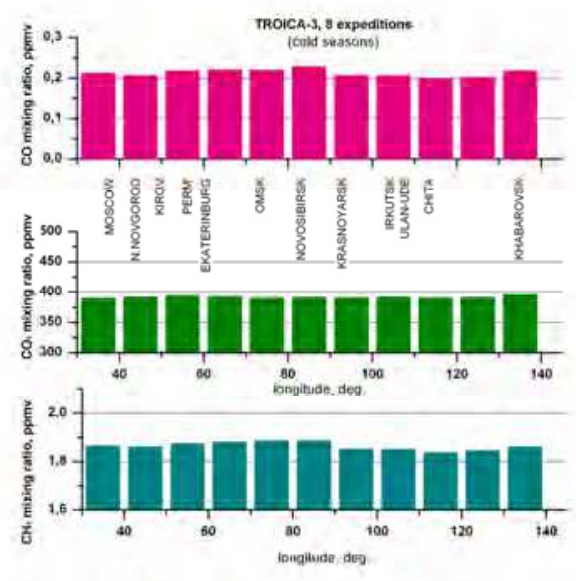

(a)

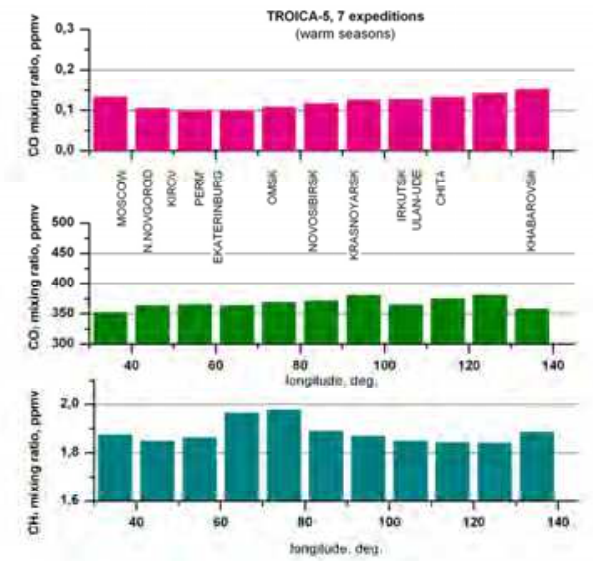

(b)

Fig. 4. Spatial distributions of the $\mathrm{CO}, \mathrm{CO}_{2}$, and $\mathrm{CH}_{4}$ mixing ratio over the continent in (a) cold and (b) warm periods (averaged over 10 degrees longitude).

$\mathrm{CH}_{4}$ mixing ratio distribution non-uniformities (Fig. 4) observed in cold periods are caused by anthropogenic sources (similar to the case of $\mathrm{CO}$ ). The enhance mixing ratio near 70-90 $\mathrm{E}$ is due to the plume of the largest in Russia Kuznetsky coil basin which is one of the important sources of atmospheric $\mathrm{CH}_{4}$ in any season. This conclusion was further confirmed using isotopic analysis of methane (Tarasova et al., 2006). In warm periods, a wellpronounced increase in the $\mathrm{CH}_{4}$ mixing ratios is observed over West Siberia. This effect is associated with intensive $\mathrm{CH}_{4}$ biogenic production by bogs.

\subsection{Isotopic composition studies}

Analysis of the carbon, oxygen, and hydrogen isotopologues of the atmospheric methane and carbon monoxide in the air samples collected from the mobile observatory was used to identify the sources of these compounds and to estimate their contribution to the global and 
regional carbon budgets. The ${ }^{13} \mathrm{C},{ }^{14} \mathrm{C},{ }^{18} \mathrm{O}$, and $\mathrm{D}$ isotopes analysis of methane and carbon monoxide in the air samples was done in Max-Planck Institute for Chemistry. $\mathrm{CH}_{4}$ isotopes measurements in the air samples were performed in the campaigns TROICA-2, 5, 7, 8 along Trans-Siberian railroad. The TROICA-5 campaign included also an exploratory expedition along the river $\mathrm{Ob}$ using a boat as a measurements platform (Oberlander et al., 2002). To identify primary processes contributing to the measured methane levels a two component mixing model was used.

Analysis of methane isotopic composition $\left({ }^{13} \mathrm{C}\right.$ and $\left.\mathrm{D}\right)$ showed that a predominant source of atmospheric methane observed in the boundary layer has a biogenic origin and is likely emitted to the atmosphere from bogs (Tarasova et al., 2006). Natural-gas leakages during the production, processing, and transportation of natural gas also contribute to the atmospheric methane levels. Shipboard measurements showed substantial increase of methane mixing ratio of up to $50 \%$ above the background level at a distance of $0.5 \mathrm{~km}$ from natural gasextraction enterprise. Methane accumulation took place under temperature inversion, while its isotopic composition has not been analyzed.

In majority of expeditions an elevated mixing ratio of $\mathrm{CH}_{4}$ was observed in the Perm region where train crosses several gas pipe lines connecting Polar Ural and Western Siberia gas fields with Central Russia. For example in the TROICA-5 the excess of $\mathrm{CH}_{4}$ reached about $200 \mathrm{ppb}$ above background mixing ratio and identified source isotopic signature $\delta^{13} \mathrm{C}_{\text {source }}=-52.42 \%$ showed the presence of the natural gas in the collected air sample.

The performed analysis (Tarasova et al., 2006) showed that biogenic methane sources play the principal role not only in Western Siberia but in other parts of Russia. At the same time for a few samples strong contributions of natural gas can be observed. In most of cases such samples were taken in the vicinity of the objects of gas industry or of the large cities (like Novosibirsk). Several examples of the city footprinted were observed in the spring campaign TROICA-8, when the strong local peaks were associated with the gas leakages from the low pressure gas distribution networks.

Analysis of the ${ }^{14} \mathrm{C}$ and ${ }^{18} \mathrm{O}$ in $\mathrm{CO}$ (Bergamaschi et al., 1998; Rochmann et al., 1999; Tarasova et al., 2007) in combination with trajectory analysis allowed identification of CO source in the summer campaign TROICA-2 as biomass burning, in particular, forest fires and combustion of agriculture waste in China. Identified sources of $\mathrm{CO}$ along the $\mathrm{Ob}$ river in the TROICA-5 campaign is likely to be connected with methane oxidation based on an inferred $\delta^{13} C_{\text {source }}=-36.8 \pm 0.6 \%$, while the value for $\delta^{18} \mathrm{O}_{\text {source }}=9.0 \pm 1.6 \%$ identifies it as burning (Tarasova et al., 2007). Thus flaring in the oil and gas production was supposed to be a source. The extreme ${ }^{13} \mathrm{C}$ depletion and concomitant ${ }^{18} \mathrm{O}$ enrichment for two of the boat samples unambiguously indicates contamination by $\mathrm{CO}$ from combustion of natural gas (inferred values $\delta^{13} \mathrm{C}_{\text {source }}=-40.3 \%$ and $\delta^{18} \mathrm{O}_{\text {source }}=17.5 \%$ ). The impact of industrial burning was discernable in the vicinity of Perm-Kungur.

\subsection{Carbon dioxide $\Delta^{14} \mathrm{CO}_{2}$}

The unique spatial distribution of ${ }^{14} \mathrm{CO} 2$ over Russia was obtained as part of TROICA- 8 expedition. The details of the method of ${ }^{14} \mathrm{CO}_{2}$ measurement in the collected flasks are 
described by Turnbull et al. (2009). It was shown that the addition of fossil fuel, ${ }^{14} \mathrm{C}$-free $\mathrm{CO}_{2}$ had the greatest influence on the spatial distribution of $\Delta{ }^{14} \mathrm{CO}_{2}$. In addition, ${ }^{14} \mathrm{CO}_{2}$ produced by nuclear reactors caused local enhancement in $\Delta{ }^{14} \mathrm{CO}_{2}$ in some samples.

$\Delta^{14} \mathrm{CO}_{2}$ increases by $5 \pm 1.0 \%$ across the transect from $40^{\circ} \mathrm{E}$ to $120^{\circ} \mathrm{E}$ (Fig. 5) and this difference is significant at the $99 \%$ confidence level. The magnitude of the $\Delta^{14} \mathrm{CO}_{2}$ gradient is consistent with the dispersion of fossil fuel $\mathrm{CO}_{2}$ emissions produced in Europe and atmospheric transport across northern Asia dispersing and diluting the fossil fuel plume. The observed isotopic change implies a gradient of $1.8 \mathrm{ppm}$ of fossil fuel derived $\mathrm{CO}_{2}$ (assuming a $-2.8 \%$ change in $\Delta{ }^{14} \mathrm{CO}_{2}$ per ppm of fossil fuel $\mathrm{CO}_{2}$ added). ${ }^{14} \mathrm{CO}_{2}$ measurements from Niwot Ridge, Colorado, USA (NWR, $40.05^{\circ} \mathrm{N}, 105.58^{\circ} \mathrm{W}, 3475$ m.a.s.l.) representing relatively clean free troposphere, give a mean $\Delta^{14} \mathrm{CO}_{2}$ value of $66.8 \pm 1.3 \%$ for 3 sampling dates during the time of the TROICA-8 campaign (grey bar in Fig. 5). The Eastern Siberian part of the TROICA transect shows values $(62.8 \pm 0.5 \%$ o $)$ most similar to the NWR value, consistent with an easterly dilution of the fossil fuel content in boundary layer air away from the primary source, but suggesting that some influence from the European fossil fuel $\mathrm{CO}_{2}$ source remains in the Eastern Siberian air mass.

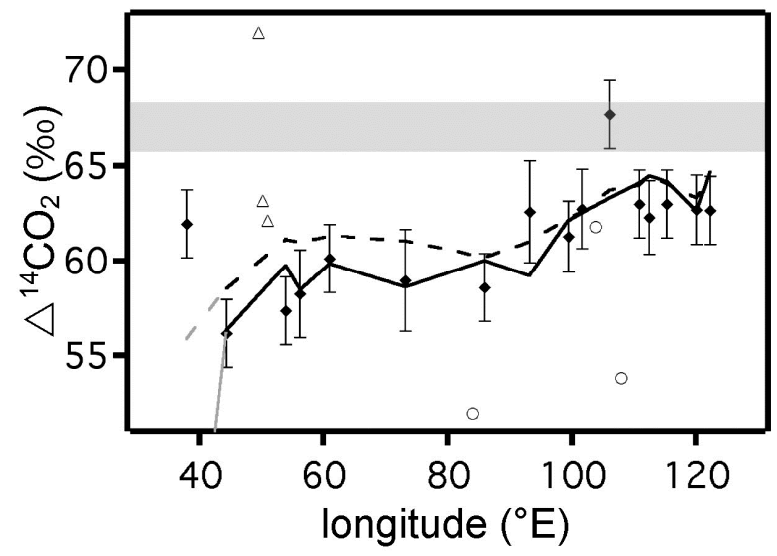

Fig. 5. $\Delta^{14} \mathrm{CO}_{2}$ as a function of longitude. Closed diamonds are the clean air $\Delta^{14} \mathrm{CO}_{2}$ dataset. Open symbols indicate samples that may be influenced by either nuclear reactor effluent (triangles) or local city pollution (circles). The shaded bar indicates the Niwot Ridge $\Delta^{14} \mathrm{CO}_{2}$ value measured over the same time period and its 1-sigma error envelope. Modeled estimates for each sampling time and location have been done on the basis standard (solid line) and fast (dashed line) mixing (see Turnbull et al., 2009).

\subsection{Volatile organic compounds}

Volatile organic compounds (VOCs) were measured in a number of expeditions (Elansky et al., 2000; Elansky et al., 2001a). VOCs were retrieved analyzing sorbent samples or in air samples pumped into stainless-steel canisters. These measurements can be performed in mobile or stationary chemical laboratories. 
Among all campaigns, the highest VOC mixing ratios were observed in summer 1999. Extremely high levels and unusual distribution of pollutants during TROICA- 5 were caused by the abnormally torrid weather that led to intense evaporation of organic substances and a high atmospheric oxidative capacity.

In the TROICA-6 experiment the mixing ratios of a number of VOCs which are important for understand of reactivity of many species were measured using a proton massspectrometer (Elansky et al., 2001a). The highest VOC mixing ratios in this campaign along the Murmansk-Kislovodsk railroad, were seen in vicinities of cities of Novocherkassk, Ryazan', Moscow and St. Petersburg. A spring zonal VOC gradient associated with a northward decrease in biogenic emissions was revealed (Table 2) over the unpolluted rural areas.

\begin{tabular}{|l|l|}
\hline Substance & Gradient, ppb $/ 1000 \mathrm{~km}$ \\
\hline Methanol & $2.37 \pm 0.11$ \\
\hline Acetonitrile & $0.08 \pm 0.01$ \\
\hline Acetaldehyde & $0.23 \pm 0.03$ \\
\hline Acetone & $0.89 \pm 0.04$ \\
\hline Isoprene, vegetable alcohols & $0.06 \pm 0.01$ \\
\hline C-pentane & $0.03 \pm 0.01$ \\
\hline Benzene & $0.07 \pm 0.01$ \\
\hline Toluene & $0.05 \pm 0.01$ \\
\hline C8-benzenes & $0.03 \pm 0.01$ \\
\hline C9-benzenes & $0.07 \pm 0.01$ \\
\hline
\end{tabular}

Table 2. Zonal gradient of VOC mixing ratios for TROICA-6 Kislovodsk-Murmansk route (May 27-29, 2000).

Detailed Trans-Siberian VOC measurements were carried out using PTR-MS during summer experiment TROICA-12 (Timkovsky et al., 2010). Figure 6 shows a spatial distribution of isoprene from Moscow to Vladivostok. This plot in particular demonstrates an influence of meteorological conditions on isoprene levels. If for the Eastern transect the weather over most of the Trans-Siberian railroad was warm and sunny, the weather was colder and less sunny of the back route (Westward). Due to these weather difference biogenic emissions in boreal and broad-leaved forests at the East of the continent on Eastern transect were more active compared with western transect which can be clearly seen in the Fig. 6. Anthropogenic emissions are mostly 'weather independent'. Observations of benzene and toluene which are connected with industrial activities or transport do not show difference between two transects of campaign. Most of peaks in the mixing ration of these compounds are associated with cities and industrial centers. 

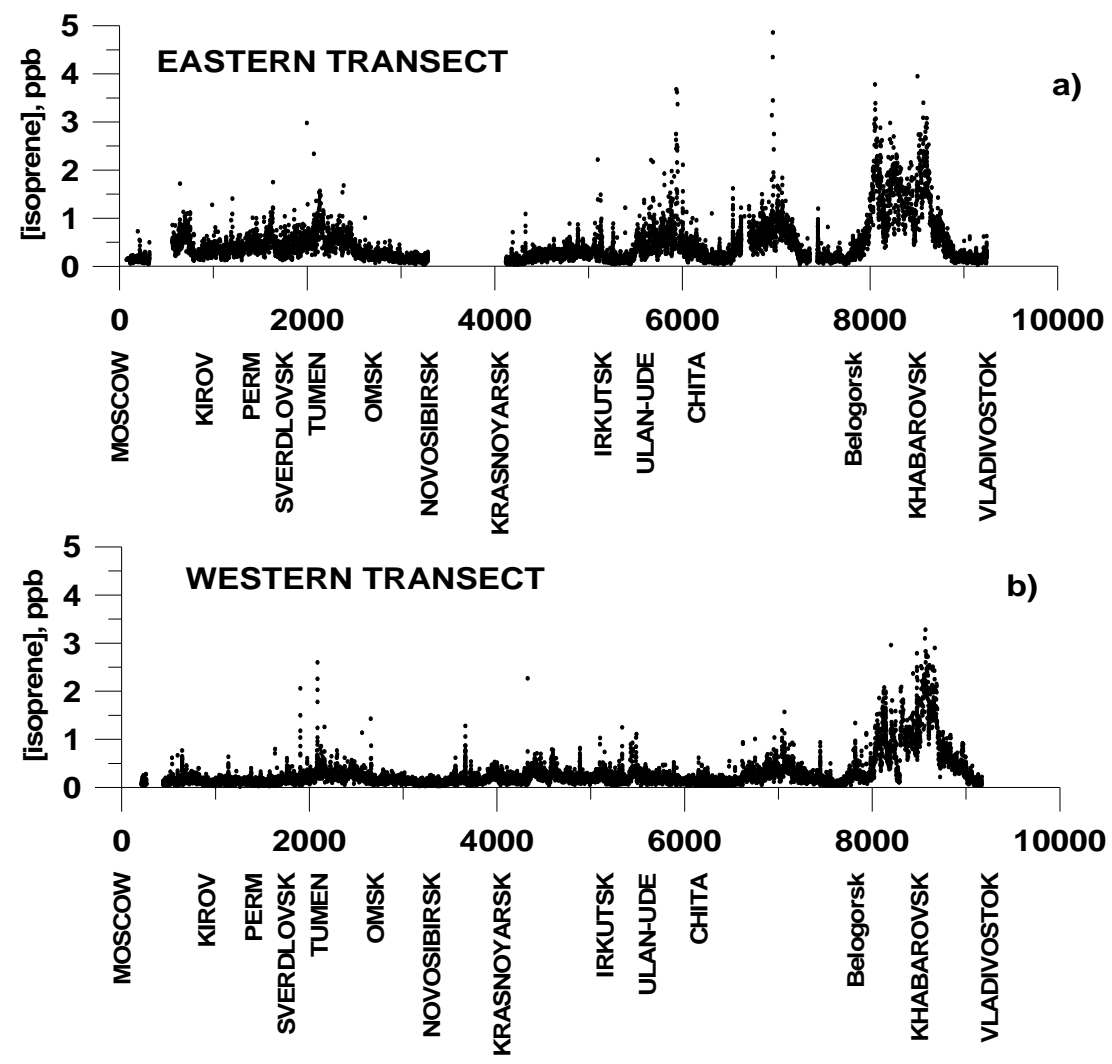

Fig. 6. Spatial distribution of isoprene mixing ratio along eastern (a) and western

(b) transects in the summer campaign of 2008 (TROICA-12).

\subsection{Aerosols}

Concentration and microphysical and chemical properties of aerosol have been measured in most of the TROICA experiments. A big archive of data on aerosol concentration, size distribution and chemical composition was collected. Up-to-now the complete analysis of these data has not been finished yet. Some results were published by Andronova et al. (2003).

Distribution of the aerosol mass concentration over the route of the TROICA campaigns is shown in Figure 7. Aerosol size distribution for unpolluted region is presented in Figure 8.

Aerosol mass was compared between rural and industrial regions. In the plumes of industrial zones and cities, the mean aerosol mass concentrations were $100-120 \mu \mathrm{g} / \mathrm{m}^{3}$. A pronounces weekly cycle was observed in these regions as well. For comparison, the rural aerosol mass concentrations varied between 10 and $20 \mu \mathrm{g} / \mathrm{m}^{3}$. In the plumes of forest fires observed by the TROICA expeditions, maximum identified aerosol mass concentrations exceeded $800 \mu \mathrm{g} / \mathrm{m}^{3}$. 
The soot aerosol concentration was measured using atmospheric aerosol sampling with quartz fiber filters and subsequent measurements of the light absorption by the aerosol samples (Kopeikin, 2007 and Kopeikin, 2008). Along the Murmansk-Kislovodsk transect, the mean level of atmospheric pollution by soot is about $1-2 \mu \mathrm{g} / \mathrm{m}^{3}$. However, the atmospheric pollution by soot is higher by an order of magnitude at the parts of the railroad where diesel locomotives are used. Large-scale (extended over 500-1000 km) non-uniformities in the soot aerosol distribution in the atmospheric boundary layer are seen during winter. In the spring of 1997, large-scale polluted zones extending over about $1000 \mathrm{~km}$ resulted from grass fires. In the winter-spring period, the atmospheric soot concentration over South Siberia and Far East were twice as high as that over European Russia. In summer, the atmosphere is weakly polluted by soot nearly along the entire railroad.

More detailed information on aerosol physical and chemical properties have been obtained by groups of specialists leaded by M.Kulmala and V.-M. Kerminen (Kuokka et. al., 2007; Vartiainen et al., 2007). During the TROICA-9 expedition the equipment for continuous monitoring of aerosol parameters with high time resolution was mounted in the moving laboratory. During this expedition the total particle concentration was typically of the order of few thousand particles $/ \mathrm{cm}^{3}$ varying between 300 and 40000 particles $/ \mathrm{cm}^{3}$. The concentrations were the lowest in the rural area between Chita and Khabarovsk and the highest near larger villages and towns. Particle concentration levels measured on the way to Vladivostok and back were similar at both ends of the route but differed in the middle, between 4000 and $7000 \mathrm{~km}$, were the concentration was notably lower on the westward route.

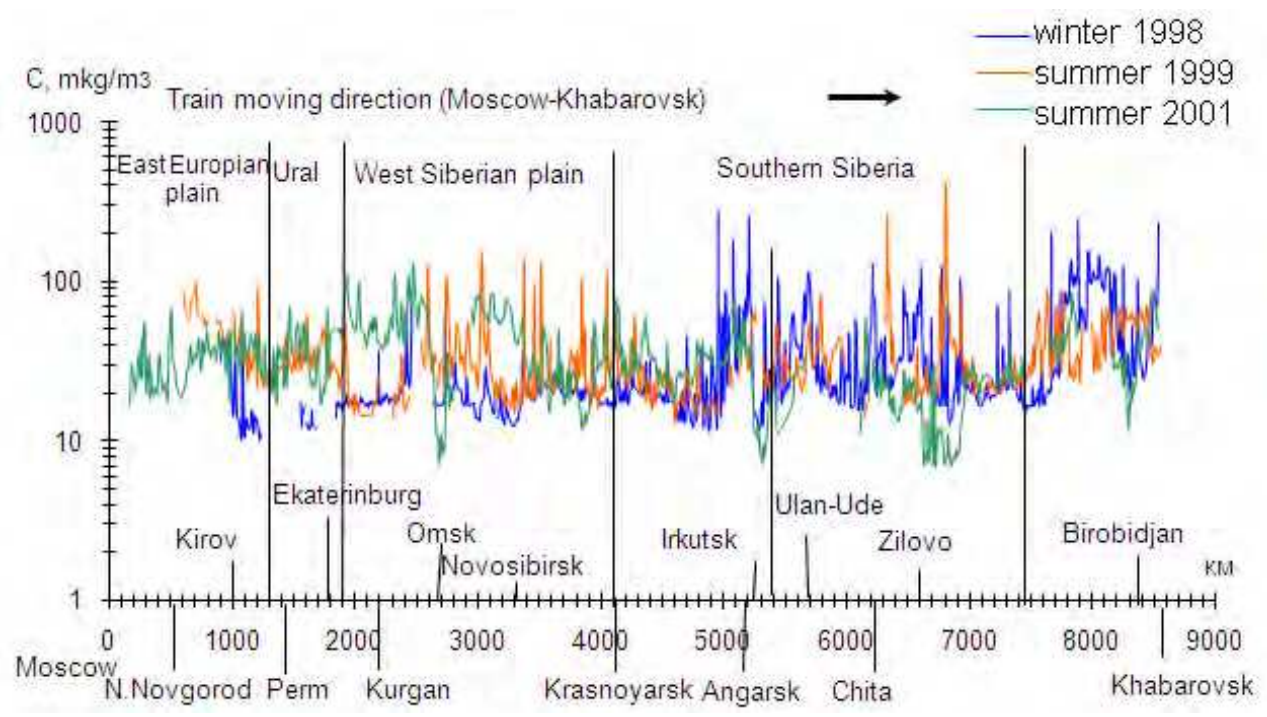

Fig. 7. Mass aerosol concentration variations along the Moscow-Khabarovsk railroad; the TROICA expeditions of 1998, 1999, and 2001. 


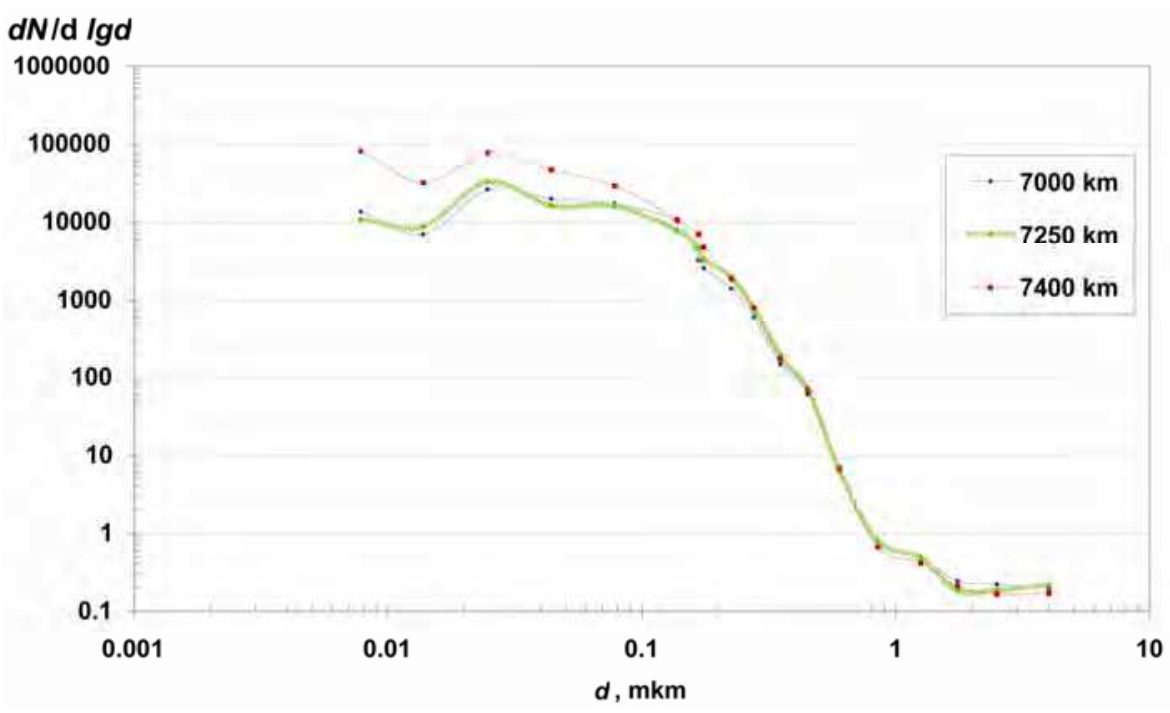

Fig. 8. Aerosol particle size distribution over the rural region covering the $7000-7400 \mathrm{~km}$ (from Moscow) railroad section (TROICA-5).

Concentrations of all ions and black carbon were quite low between the 3500 and $6500 \mathrm{~km}$ from Moscow, whereas high concentrations were observed between Moscow and Novosibirsk and in Asia before and after Khabarovsk on both (going to Vladivostok and coming back to Moscow) routes. On the way back to Moscow, the concentrations of all ions and black carbon were at extremely high levels near Khabarovsk. It was shown using trajectory analysis that high concentration events were mostly associated with long-range transport of aerosol particles from North-East China. The increased potassium and oxalate concentrations in this area are indicative of biomass burning.

Detailed analysis of the TROICA-9 aerosol measurements showed that fine particles consisted mainly of soot (BC, 15.8-48.7\%, average $27.6 \%), \mathrm{SO}_{4}{ }^{2-}(2.7-33.5 \%, 13.0 \%)$, $\mathrm{NH}_{4}{ }^{+}(1.2-10.5 \%, 4.1 \%)$, and $\mathrm{NO}_{3}{ }^{-}(0.5-2.4 \%, 1.4 \%)$. Trace metals in total accounted for $0.4-$ $9.8 \%$ of the fine particulate mass. The fraction of monosaccharide anhydrides was in the range $0.4-1.6 \%$, except for one sample (5926-7064 $\mathrm{km}$ from Moscow) on the way to Vladivostok where it was as high as $4 \%$. The measured chemical components accounted for 27.7-78.5\% of the PM2.5 mass. The unidentified fraction is expected to include organic particulate matter, water-insoluble material and water. The contribution of BC to PM2.5 was much higher during the whole TROICA-9 expedition than the fraction observed in Europe, where the BC contribution was estimated to be in the range 5-10\% (Kuokka et al., 2007).

\section{Air pollution in cities}

The mobile laboratory provides an opportunity to study air pollution in the cities along the expedition route. The cross-sections of the cities and individual pollution plumes from different sources under different conditions can help to estimate the intensity of different anthropogenic sources. Topography, vegetation structure and state and a number of other 
factors are also important for the formation of city plumes in addition to meteorological factors. Figure 9 gives an example of the atmospheric pollutants distribution measured under different wind directions along the railroad traversing the city of Tyumen'. The structure of the spatial NO distribution demonstrates that several distinct sources are responsible for the formation of the observed NO levels in the city. These sources were the same for the movement of expedition in both directions. Observed differences of the plume on the ways forward and back are caused by the plume shift resulted from the winddirection variation (different remoteness of the sources from the railroad).

During the TROICA expeditions, the train travelling along the Trans-Siberian Railroad crossed repeatedly about 110 cities with a population from 20 to 1500 thousand people (except Moscow). In addition, several tens of cities were crossed by the train in the course of the Kislovodsk-Murmansk expedition (TROICA-6). One particular expedition (TROICA-10) was aimed at the studying of the atmosphere composition around Moscow megacity.

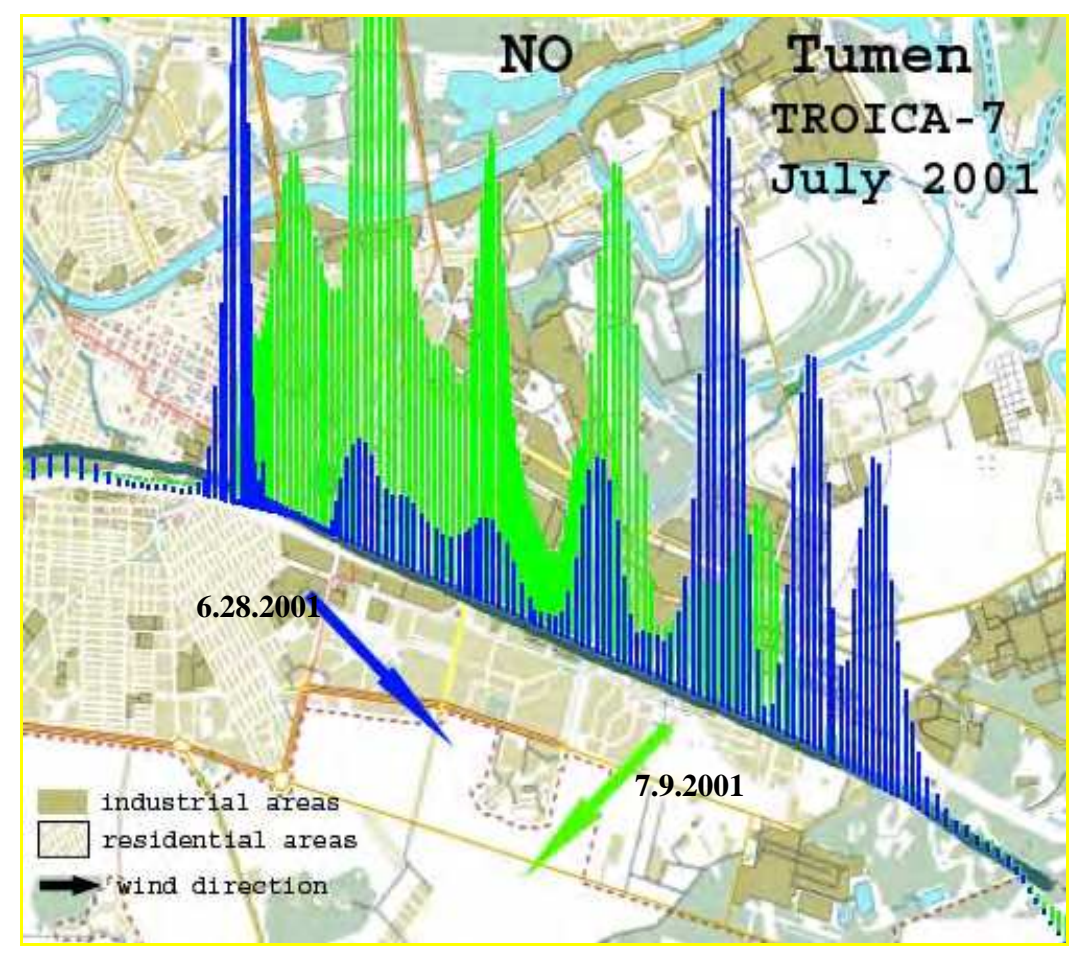

Fig. 9. Transects of Tumen' city on the routes eastward and westward. The structure of the plume profile from city's air pollution sources at the railroad depends on the wind direction.

Comparison of the different pollutants profile across the cities of different size (Table 3) is presented on Fig. 10. Observations show that ozone mixing rations in the cities are slightly lower than the ozone mixing ratios in rural areas due to ozone destruction by nitrogen oxides in urban air. Ozone mixing ratio in the cities of all sizes is the highest in 
spring. Spring maximum of ozone mixing ratio is typical for unpolluted sites of midlatitudes, while most of big cities are characterized by the broad spring-summer maximum with a clear dominance of the summer levels. Ozone destruction intensity in polluted air is significantly higher in Moscow than in the other Russian cities located along the Trans-Siberian railroad, where ozone behavior corresponds, on average, to the one in slightly polluted areas.

\begin{tabular}{|l|l|l|}
\hline City groups & Population & Number of cities \\
\hline Large & $>500000$ & 11 \\
\hline Middle & $50000 \div 500000$ & 34 \\
\hline Small & $<50000$ & 62 \\
\hline
\end{tabular}

Table 3. Cities statistics according to population.

In all seasons (Fig. 10) mixing ratio of ozone precursors decreases in the city plumes. The daytime ozone mixing ratios exceed the background level in the medium and small size cities. Ozone destruction by nitrogen oxides prevails over ozone generation within large cities. During the warm period ozone mixing ratios in the cities' plume are comparable with the background (some generation takes place). More active ozone generation leading to the small exceed over background levels is observed in the plumes of the medium size and small size cities.

The level of atmospheric pollution characteristic for cold seasons exceeds significantly that characteristic for warm seasons due to the contribution of urban heating systems and coal heating systems functioning in passenger cars at railroad stations.

The daily variations of the primary pollutants in the cities are determined by the primary emissions, including traffic, and they are in less degree dependent on the functioning of industrial enterprises (Elansky et al., 2007). Pollution levels are influenced by the set up and destruction of temperature inversions, which are rather intensive in Siberia. If morning and evening rush hours often coincide with the inversion period, fast accumulation of pollutants in the boundary layer occurs. Such situations are quite common during cold seasons. In summer the duration and magnitude of the night temperature inversions is less than in cold period, diurnal peak of emissions occurs during the hours with substantial air mixing processes, which prevents accumulation of primary pollutants in the boundary layer.

Change of the pollution level in the cities gets clear when comparing observations of the primary pollutants level during different years. This difference is clearly related to city traffic grows and intensification of industrial activities after the economic crisis of 1991-1995. This correlation is illustrated by the Figures $11(a, b)$, where NOx and CO mixing ratio trends calculated on the basis of the measurements performed in the course of 1996-2007 expeditions are shown. Fig. 11 shows a trend in the number of motor vehicles in Russian cities, which correlates with the observed changes in the primary pollutants levels. 

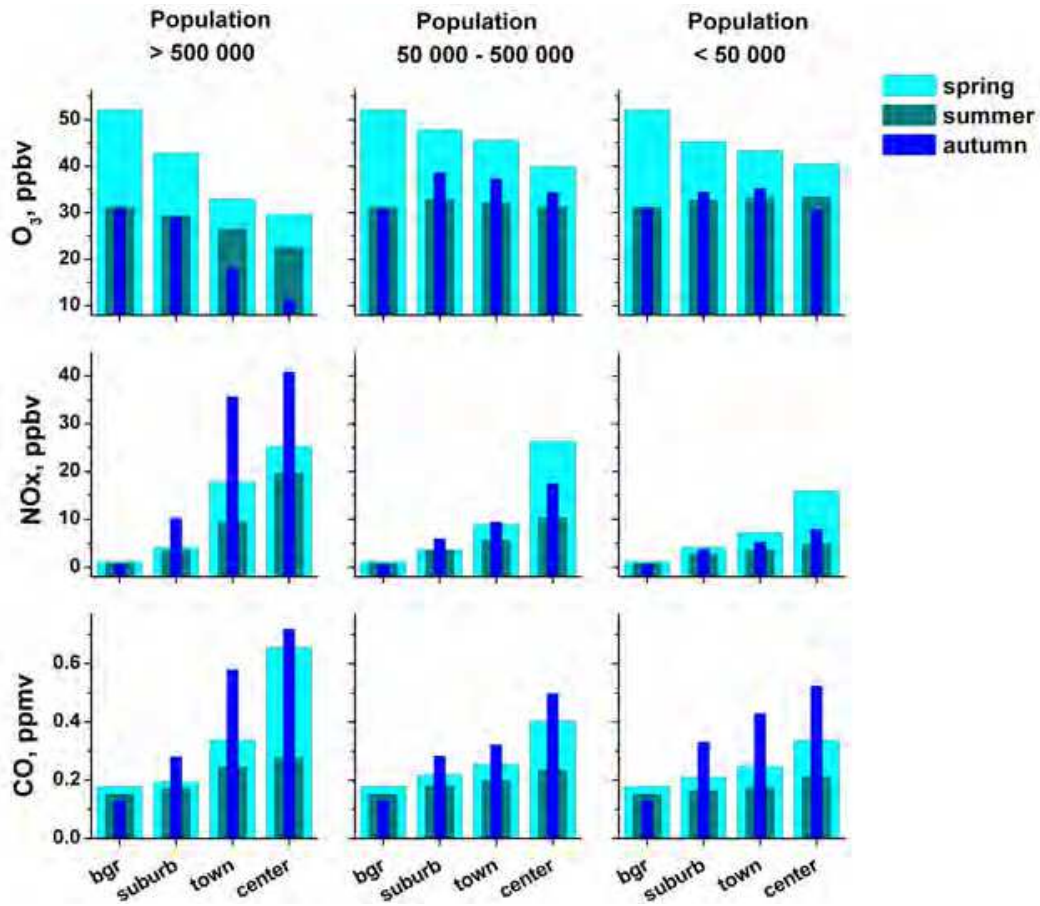

Fig. 10. Daytime mean (11:00-18:00 h. local time) $\mathrm{O}_{3}, \mathrm{NOx}, \mathrm{CO}$ mixing ratios averaged over the background (brg) and different parts of cities territories for spring, summer and autumn and for three groups of cities (TROICA-3 - TROICA-11).

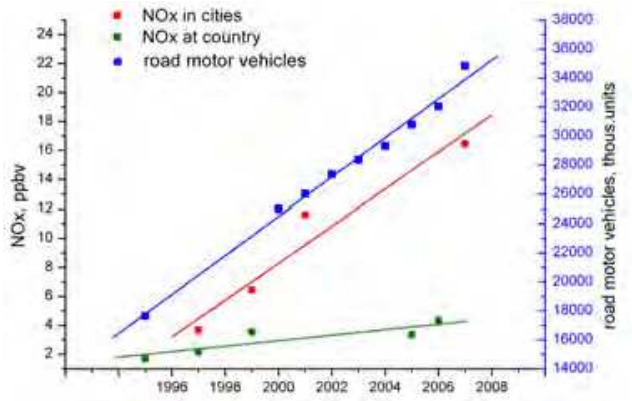

(a)

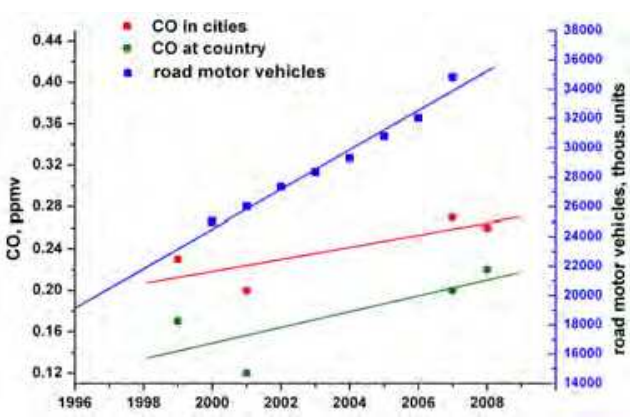

(b)

Fig. 11. The growth of the number of road motor vehicles in Russia and mean summer (a) NOx and (b) CO mixing ratios in cities and outside cities (TROICA-2,5,7,11 experiments).

\section{Local impacts of railway transport on the atmospheric composition}

The adverse effects of railroad systems on the environment are due to effects/emissions of stationary industrial objects (freight terminals, repair plants and depots) and freight and passenger trains themselves. The latter one is due abrasion of solid surfaces of car and 
locomotive components, pouring, leaking, and dusting out of transported loads, emissions from locomotive diesels and coal car-heating boilers. Large amounts of solids of different chemical species can be blown away from the trains transporting ores, coal, and other loose goods. Upward airflows blow solid particles up from the railroad bed. The majority of these particles are coarse, and, therefore, they are deposited back to the surface rather quickly.

Figures 12 and 13 demonstrate an effect of oncoming freight trains on the size distribution and aerosol mass concentrations measured by mobile laboratory. An abrupt increase of the portion of coarse particles after the passage of oncoming trains is caused by the lifting of solid particles from railroad beds and from freight cars. In contrast, oncoming trains have almost no influence on the atmospheric concentration of fine particles. An abrupt increase in the aerosol concentration is observed immediately after the passage of oncoming trains. The height of the concentration peak depends on the length and speed of the oncoming train and on its type: long freight trains increase aerosol concentrations to a greater extent than the passenger trains do.

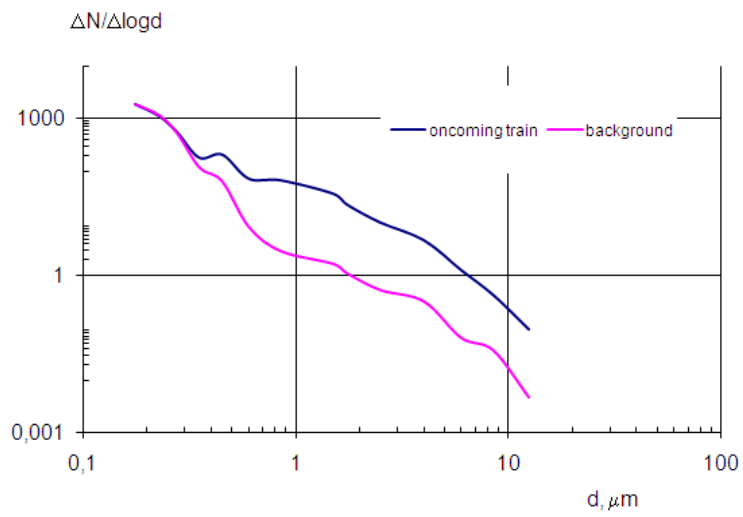

Fig. 12. Effect of oncoming trains on the aerosol size distribution.

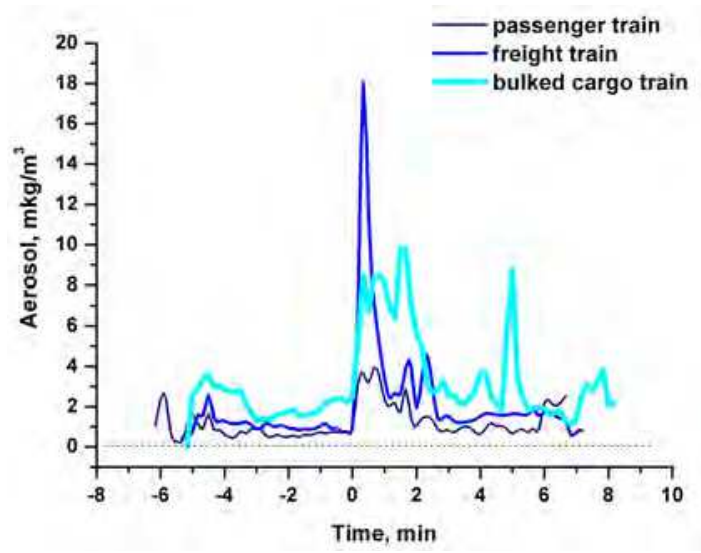

Fig. 13. Aerosol concentration peaks caused by the passage of oncoming trains of different types. 
Enhanced atmospheric mixing ratios of unsaturated hydrocarbons (UHCs) were measured when trains containing oil-gasoline tanks passed by and also in vicinities of stations and siding lines where similar tanks were concentrated (Fig. 14). Emissions caused by trains consisting of tanks only and of different cars, including tanks, were estimated. The degree of UHC enhancement depends on the tank quantity in the train, the type of the transported good, hermeticity of the tank hatches, wind speed and direction, air temperature, and landscape.

It is important that hatches of empty railroad oil-gasoline tanks are open to avoid explosive vapor concentrations within tanks containing hydrocarbon residuals. As it can be seen in Fig. 14 the highest peaks are associated with the empty oil tank wagons. It should be noted that the effects of the train on the observed changes of the atmosphere composition are very local and can be seen only in the data of the highest spatial resolution. Other examples of the local-scale effects (power lines and industrial plumes) can be found in the relevant publications (Elansky \& Nevraev, 1999; Elansky et al., 2001c).

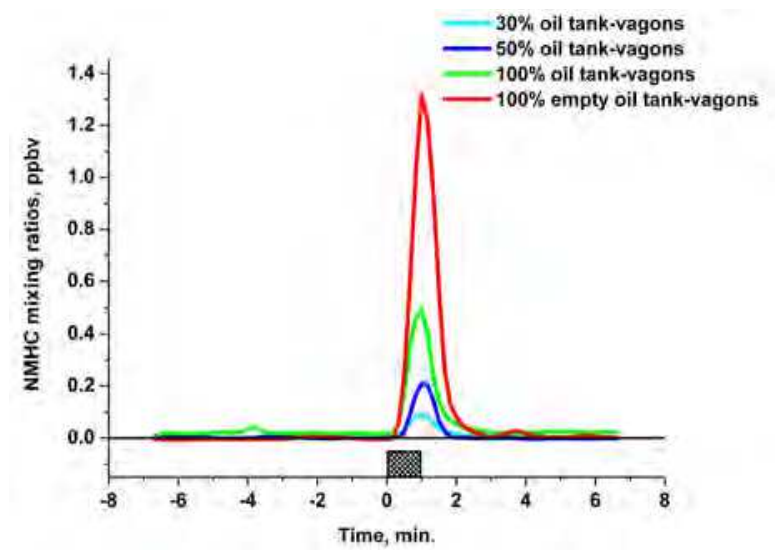

Fig. 14. Atmospheric UHC mixing ratios enhancement associated with oncoming trains with oil-gasoline tanks.

\section{Conclusions}

Researchers and engineers from different countries participated in the TROICA experiments. Due to close cooperation and unification of technical capabilities new and important results which increased our knowledge about atmospheric conditions above the North Eurasia were obtained. The mobile laboratory was a basis for this work. The laboratory was specially developed and constructed to carry out observations on the network of electrified railroads in the countries of the former Soviet Union.

By January 2009, the TROICA laboratory was equipped with the up-to-date measuring system for many atmospheric parameters. Field testing of the laboratory performed in the framework of the TROICA International Experiments showed that this laboratory has unique characteristics and has a number of advantages over other Russian means of monitoring the atmospheric gaseous and aerosol constituents:

- $\quad$ wide variety of the parameters can be measured, including most of the key gaseous and aerosol pollutants, the radiative and thermodynamic parameters characterizing 
atmospheric photochemical activity, and the parameters describing transport and deposition of atmospheric components;

- wide range of detectable mixing ratios variability from small natural variations of potential pollutants in the non-polluted atmosphere to the extreme variations of pollutants under critical conditions;

- multi-functionality, namely, simultaneous observations of the different species in different media (in atmosphere, water, soils, and vegetation bodies) which allows for direct observations of pollution on the state of ecosystems and on the environment;

- conformance with the international standards, namely, the instruments applied at the TROICA laboratory are supplied with international certificates, and undergo regular calibrations and standard validations of their applicability;

- universality of the measuring methods used in the moving platform, namely, individual elements of the instrumentation can be transported into other mobile platform or any buildings and installed there as mobile or stationary observational stations, and, in addition, simplified variants of the measuring system and software can be replicated and used for equipping the future Russian network stations;

- on-line functioning, namely, the software allows on-line analysis of the measurements, numerical simulation of photochemical and dynamic processes, prediction of extreme ecological situations, and on-line danger warning on the basis of satellite communications.

The support of TROICA experiments by the International Science and Technology Center played a very important role. The center united many organizations and made collaboration very efficient.

Accumulated data have proven to have a high potential to be further used for models (Tarasova et al., 2009) and satellite observations validation as well as provided better understanding of the atmosphere composition features over substantial part of the Russian territory.

\section{References}

Andronova, A.V.; Granberg, I.G.; Iordansky, M.A.; Kopeikin, V.M.; Minashkin, M.A.; Nevsky, I.A. \& Obvintsev, Yu.I. (2003). Studies of the Spatial and Temporal Distribution of Surface Aerosol along the Trans-Siberian Railroad. Izvestiya, Atmospheric and Oceanic Physics, Vol. 39, Suppl. 1, pp. S27-S34.

Belikov, I. B.; Brenninkmeijer, C. A. M.; Elansky, N. F. \& Ral'ko, A. A. (2006). Methane, carbon monoxide, and carbon dioxide concentrations measured in the atmospheric surface layer over continental Russia in the TROICA experiments. Izvestiya, Atmospheric and Oceanic Physics, Vol.42, Issue 1, pp. 46-59.

Bergamaschi P.; Brenninkmeijer, C.A.M.; Hahn, M.; Rockmann, T.; Schaffe, D.; Crutzen, P.J.; Elansky, N.F.; Belikov, I.B.; Trivett, N.B.A. \& Worthy, D.E.J. (1998). Isotope analysis based on source identification for atmospheric $\mathrm{CH}_{4}$ and $\mathrm{CO}$ sampled across Russia using the Trans-Siberian railroad. J.Geophys.Res., Vol. 103, No. D7, pp. 8227-8235.

Crutzen, P.J.; Golitsyn, G.S.; Elansky, N.F.; Brenninkmeijer, C.A.M.; Scharffe, D.; Belikov, I.B. \& Elokhov, A.S. (1996). Monitoring of the atmospheric pollutants over the Russian territory on the basis of a railroad mobile laboratory. Dokl. Akad. Nauk, Vol. 350, No. 6, pp. 819-823.

Crutzen, P.J.; Elansky, N.F.; Hahn, M.; Golitsyn, G.S.; Brenninkmeijer, C.A.M.; Scharffe, D.; Belikov, I.B.; Maiss, M.; Bergamaschi, P.; Rockmann, T.; Grisenko, A.M. \& 
Sevastyanov, V.V. (1998). Trace gas measurements between Moscow and Vladivostok using the Trans-Siberian Railroad. Journal of Atmospheric Chemistry, No. 29, pp. 179-194.

Elansky, N.F. \& Nevraev, A.N. (1999). The electric tension lines as a possible source of ozone in the troposphere. Doklady Earth Sciences, Vol. 365, No. 4, pp. 533-536.

Elansky, N.F.; Golitsyn, G.S.; Vlasenko, T.S. \& Volokh, A.A. (2000). Volatile organic compounds observed in the atmospheric surface layer along the Trans-Siberian Railroad. Dokl. Akad. Nauk, Vol. 373, No. 6, pp. 816-821.

Elansky, N.F.; Golitsyn, G.S.; Vlasenko, T.S. \& Volokh, A.A. (2001a). Concentrations of Volatile Organic Compounds in Surface Air along the Trans-Siberian Railroad. Izvestiya, Atmospheric and Oceanic Physics, Vol. 37, Suppl. 1, pp. S10-S23.

Elansky, N.F.; Markova, T.A.; Belikov, I.B. \& Oberlander, E.A. (2001b). Transcontinental Observations of Surface Ozone Concentration in the TROICA Experiments: 1. Space and Time Variability. Izvestiya, Atmospheric and Oceanic Physics, Vol. 37, Suppl. 1, pp. S24 - S38.

Elansky, N.F.; Panin, L.V. \& Belikov, I.B. (2001c). Influence of High-Voltage Transmission Lines on Surface Ozone Concentration. Izvestiya, Atmospheric and Oceanic Physics, Vol. 37, Suppl. 1, pp. S92-S101.

Elansky, N.F.; Lokoshchenko, M. A.; Belikov.; Skorokhod, A.I. \& Shumskii, R.A. (2007). Variability of Trace Gases in the Atmospheric Surface Layer from Observations in the City of Moscow. Izvestiya, Atmospheric and Oceanic Physics, Vol. 43, No. 2, pp. 219-231.

Elansky, N. F. (2007). Observations of the atmospheric composition over Russia using a mobile laboratory: the TROICA experiments. International Global Atmospheric Chemistry. Newsletter, No. 37, pp. 31-36.

Elansky, N.F.; Belikov, I.B; Berezina, E.V; et al. (2009). Atmospheric composition observations over Northern Eurasia using the mobile laboratory: TROICA experiments. ISTC. Moscow. 72 p.

Golitsyn, G.S.; Elansky, N.F.; Markova, T.A. \& Panin, L.V. (2002). Surface Ozone behavior over Continental Russia. Izvestiya, Atmospheric and Oceanic Physics, Vol. 38, Suppl. 1, pp. S116-S126.

Hurst, D.F.; Romashin, P.A.; Elkins, J.W.; Oberlander, E.A.; Elansky, N.F.; Belikov, I.B.; Granberg, I.G.; Golitsyn, G.S.; Grisenko, A.M.; Brenninkmeijer, C.A.M. \& Crutzen, P.J. (2004). Emissions of ozone-depleting substances in Russia during 2001. J. Geophys. Res., Vol. 109, No. D14303, doi: 10.1029/2004JD004633.

Kopeikin, V.M. (2007). Monitoring of the soot aerosol of the atmosphere over Russia the TROICA international experiments. Atmospheric and oceanic optics, Vol. 20, No. 7, pp. $641-646$.

Kopeikin, V.M. (2008). Monitoring of the submicron aerosol content of the atmosphere over Russia the TROICA international experiments. Atmospheric and oceanic optics, Vol. 21, No. 11, pp. 970 - 976.

Kuokka, S.; Teinilä, K.; Saarnio, K..; Aurela, M.; Sillanpää, M.; Hillamo, R.; Kerminen, V.-M.; Pyy, K.; Vartiainen, E.; Kulmala, M.; Skorokhod, A. I.; Elansky, N.F. \& Belikov, I.B. (2007). Using a moving measurement platform for determining the chemical composition of atmospheric aerosols between Moscow and Vladivostok. Atmos. Chem. and Phys., V. 7, No 18, 4793-4805.

Markova, T.A. \& Elansky., N.F. (2002). Transcontinental Observations of the Surface Ozone and Nitrogen Oxide concentrations by using the Carriage-Laboratory. Ed. I. Barnes, Global Atmospheric Change and its Impact on Regional Air Quality, Kluwer Academic Publishers, Netherlands, pp. 249-254. 
Markova, T.A.; Elansky, N.F.; Belikov, I.B.; Grisenko, A.M. \& Sevast'yanov, V.V. (2004). Distribution of nitrogen oxides in the atmospheric surface layer over continental Russia, Izvestiya, Atmospheric and Oceanic Physics, Vol. 40, No. 6, pp. 811-813.

Oberlander, E.A.; Brenninkmeijer, C.A.M.; Crutzen, P.J.; Elansky, N.F.; Golitsyn, G.S.; Granberg, I.G.; Scharffe, D.H.; Hofmann, R.; Belikov, I.B.; Paretzke, H.G. \& van Velthoven, P.F.J. (2002). Trace gas measurements along the Trans-Siberian railroad: The TROICA 5 expedition. J.Geophys.Res., Vol. 107, No. D14, doi: 10.1029/2001JD000953.

Panin, L.V.; Elansky, N.F.; Belikov, I.B.; Granberg, I.G.; Andronova, A.V.; Obvintsev, Yu.I.; Bogdanov, V.M.; Grisenko, A.M. \& Mozgrin, V.S. (2001). Estimation of Reliability of the Data on Pollutant Content Measured in the Atmospheric Surface Layer in the TROICA Experiments. Izvestiya, Atmospheric and Oceanic Physics, Vol. 37, Suppl. 1, pp. S81-S91.

Rockmann, T.; Brenninkmeijer, C.A.M.; Hahn, M.\& Elansky, N. (1999). CO mixing and isotope ratios across Russia; trans-Siberian railroad expedition TROICA 3, April 1997. Chemosphere: Global Change Science, No. 1, pp. 219-231.

Shakina, N.P.; Ivanova, A.R.; Elansky, N.F. \& Markova, T.A. (2001). Transcontinental Observations of Surface Ozone Concentration in the TROICA Experiments: 2. The Effect of the Stratosphere-Troposphere Exchange. Izvestiya, Atmospheric and Oceanic Physics, Vol. 37, Suppl. 1, pp. S39 - S48.

Tarasova, O.A.; Brenninkmeijer, C.A.M.; Assonov, S.S.; Elansky, N.F \& Hurst, D.F. (2005a). Methane variability measured across Russia during TROICA expeditions. Environmental Sciences, Vol. 2(2-3), pp. 241-251.

Tarasova, O.A.; Brenninkmeijer, C.A.M.; Elansky, N.F. \& Kuznetsov, G.I. (2005b). Studies of variations in the carbon monoxide concentration over Russia from the data of TROICA expeditions. Atmospheric and Oceanic Optics, Vol. 18, No. 5-6, pp. 511-516.

Tarasova, O.A.; Brenninkmeijer, C. A. M.; Assonov, S.S.; Elansky, N. F.; Röckmann, T. \& Brass, M. (2006). Atmospheric CH4 along the Trans-Siberian Railroad (TROICA) and River Ob: Source Identification using Stable Isotope Analysis. Atmospheric Environment, Vol. 40. No. 29, pp. 5617-5628.

Tarasova, O.A.; Brenninkmeijer, C. A. M.; Assonov, S.S.; Elansky, N.F.; Röckmann, T. \& Sofiev, M. A. (2007). Atmospheric CO along the Trans-Siberian Railroad and River Ob: Source Identification using Isotope Analysis. J. Atmos. Chem., Vol. 57, No. 2, pp. 135-152.

Tarasova, O.A.; Houweling, S.; Elansky, N. \& Brenninkmeijer, C.A.M. (2009). Application of stable isotope analysis for improved understanding of the methane budget: comparison of TROICA measurements with TM3 model simulations. J. Atmos. Chem., Vol. 63, No. 1, pp. 49-71

Timkovsky, I. I.; Elanskii, N. F.; Skorokhod, A. I. \& Shumskii, R. A. (2010). Studying of Biogenic Volatile Organic Compounds in the Atmosphere over Russia. Izvestiya, Atmospheric and Oceanic Physics, Vol. 46, No. 3, pp. 319-327.

Turnbull, J. C.; Miller, J. B.; Lehman, S. J.; Hurst, D. .; Peters, W.; Tans, P. P.; Southon, J.; Montzka, S.; Elkins, J.; Mondeel, D. J.; Romashkin, P. A.; Elansky, N. \& Skorokhod, A. (2009). Spatial distribution of $\Delta^{14} \mathrm{CO}_{2}$ across Eurasia: measurements from the TROICA-8 expedition. Atmos. Chem. and Phys., Vol. 9, pp. 175-187.

Vartiainen, E.; Kulmala, M.; Ehn, M.; Hirsikko, A.; Junninen, H.; Petäjä, T.; Sogacheva, L.; Kuokka, S., Hillamo, R., Skorokhod, A., Belikov, I., Elansky, N. \& Kerminen, V.-M. (2007). Ion and particle number concentrations and size distributions along the Trans-Siberian railroad. Boreal. Env. Res., Vol. 12, No. 3, pp. 375-396. 


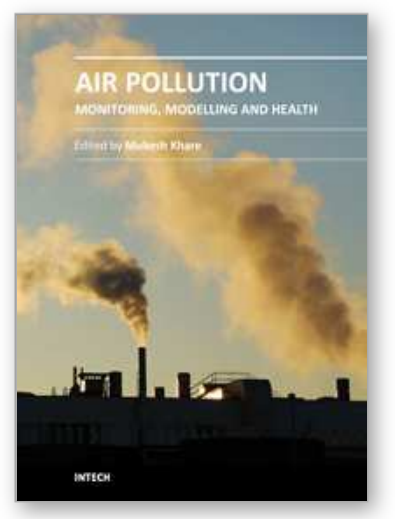

\author{
Air Pollution - Monitoring, Modelling and Health \\ Edited by Dr. Mukesh Khare
}

ISBN 978-953-51-0424-7

Hard cover, 386 pages

Publisher InTech

Published online 23, March, 2012

Published in print edition March, 2012

Air pollution has always been a trans-boundary environmental problem and a matter of global concern for past many years. High concentrations of air pollutants due to numerous anthropogenic activities influence the air quality. There are many books on this subject, but the one in front of you will probably help in filling the gaps existing in the area of air quality monitoring, modelling, exposure, health and control, and can be of great help to graduate students professionals and researchers. The book is divided in two volumes dealing with various monitoring techniques of air pollutants, their predictions and control. It also contains case studies describing the exposure and health implications of air pollutants on living biota in different countries across the globe.

\title{
How to reference
}

In order to correctly reference this scholarly work, feel free to copy and paste the following:

N.F. Elansky, I.B. Belikov, O.V. Lavrova, A.I. Skorokhod, R.A. Shumsky, C.A.M. Brenninkmeijer and O.A. Tarasova (2012). Train-Based Platform for Observations of the Atmosphere Composition (TROICA Project), Air Pollution - Monitoring, Modelling and Health, Dr. Mukesh Khare (Ed.), ISBN: 978-953-51-0424-7, InTech, Available from: http://www.intechopen.com/books/air-pollution-monitoring-modelling-and-health/train-basedplatform-for-observations-of-atmosphere-composition-troica-project-

\section{INTECH}

open science | open minds

\section{InTech Europe}

University Campus STeP Ri

Slavka Krautzeka 83/A

51000 Rijeka, Croatia

Phone: +385 (51) 770447

Fax: +385 (51) 686166

www.intechopen.com

\section{InTech China}

Unit 405, Office Block, Hotel Equatorial Shanghai

No.65, Yan An Road (West), Shanghai, 200040, China

中国上海市延安西路65号上海国际贵都大饭店办公楼405单元

Phone: +86-21-62489820

Fax: $+86-21-62489821$ 
(C) 2012 The Author(s). Licensee IntechOpen. This is an open access article distributed under the terms of the Creative Commons Attribution 3.0 License, which permits unrestricted use, distribution, and reproduction in any medium, provided the original work is properly cited. 